she has fostered the dissemination of relevant scientific information by her work for Mouse News Letter and its successor, Mouse Genome, e.g. as Editor from 1956 to 1970 , more recently as a Chairman of Mouse News Letter Ltd and in many other ways. Equally important has been her service on the Committee for Standardized Genetic Nomenclature for Mice, which she joined in 1958 and has chaired since 1975. It is through her vigilance, foresight, powers of persuasion and sheer hard work that mouse genetic nomenclature is in its present satisfactory state, without any of the confusion and uncertainty which could easily have dogged such a rapidly advancing science. Thirdly, she found time among all her other activities to co-edit a new and greatly enlarged edition of Genetic Variants and Strains of the Laboratory Mouse, bearing her full share of all the extra work which that involved. It is also worth mentioning here that she has served or is serving on the Editorial Boards of at least eleven journals besides Genetical Research. She also officiated as Hon. Treasurer of the Genetical Society for a number of years and later as Vice-President.

Mary's scientific achievements led to her election in 1973 as Fellow of the Royal Society, which awarded her a Royal Medal in 1984. In 1979 she was elected a

\section{Bibliography of Mary Lyon}

1. Lyon, M. F. Hereditary absence of otoliths in the house mouse. J. Physiol. 114, 410-418. 1951

2. Lyon, M. F. Absence of otoliths in the mouse: an effect of the pallid mutant. J. Genet. 51, 638-650. 1953

3. Kaplan, W. D. \& Lyon, M. F. Failure of mercaptoethylamine to protect against the mutagenic effects of radiation. I. Experiments with Drosophila. Science 118, 776-777. 1953

4. Kaplan, W. D. \& Lyon, M. F. Failure of mercaptoethylamine to protect against the mutagenic effects of radiation. II. Experiments with mice. Science 118, 777-778. 1953

5. Carter, T. C., Lyon, M. F. \& Phillips, R. J. S. Induction of sterility in male mice by chronic gamma irradiation. Brit. J. Radiol. 27, 418-422. 1954

6. Carter, T. C., Lyon, M. F. \& Phillips, R. J. S. Partial sex linkage in the mouse. Nature 174, 309. 1954

7. Lyon, M. F. Stage of action of the litter-size effect on absence of otoliths in mice. Z. indukt, Abstamm. $u$. Vererb. Lehre. 86, 289-292. 1954

8. Carter, T. C., Lyon, M. F., Phillips, R. J. S. \& Slizynski, B. M. Cytogenetic studies of the mouse, using Xray induced translocations. Caryologia 6 Suppl. 10467. 1954

9. Carter, T. C., Lyon, M. F. \& Phillips, R. J. S. Genetagged chromosome translocations in eleven stocks of mice. J. Genet. 53, 154-166. 1955

10. Lyon, M. F. Ataxia: a new recessive mutant of the house mouse. J. Hered. 46, 77-80. 1955

11. Lyon, M. F. The developmental origin of hereditary absence of otoliths in mice. J. Embryol. exp. Morph. 3, 230-241. 1955

12. Lyon, M. F. The development of the otoliths of the mouse. J. Embryol. exp. Morph. 3, 213-229. 1955
Foreign Associate of the US National Academy of Sciences, also a Foreign Honorary Member of the American Academy of Arts and Sciences in 1980. She is an Honorary Fellow of her old College, Girton, and has received many other honours and awards.

Despite her imminent 'retirement', Mary continues to work with the efficiency and drive for which she is noted, making full use of the latest techniques and computer wizardry. Transgenic mice are now tools for further investigation of the $t$-complex, the wide array of $p$ mutations is receiving closer attention but, more evident still, is her considerable interest in unravelling genomic regions of man-mouse homology, with her Mouse Chromosome Atlas as a very elegant way of illustrating these. With funds to continue this work, Mary's retirement looks set to be purely nominal and, with freedom from administrative chores, we hope she can enjoy many more years of exciting research and disco very with her colleagues.

Mary, we salute you! Thanks for everything and best wishes for the future!

Bruce Cattanach
Jo Peters
Tony Searle

13. Carter, T. C., Lyon, M. F. \& Phillips, R. J. S. Induction of mutations in mice by chronic gamma irradiation; interim report. Brit.J. Radiol. 29, 106-108. 1956

14. Lyon, M. F. Hereditary hair loss in the tufted mutant of the house mouse. J. Hered. 47, 101-103. 1956

15. Lyon, M. F. Genetics and laboratory animal breeding. J. Anim. Tech. Ass. 7, 9-11. 1956

16. Carter, T. C., Lyon, M. F. \& Phillips, R. J. S. Further genetic studies of eleven translocations in the mouse. J. Genet. 54, 462-473. 1956

17. Lyon, M. F. Twirler: a mutant affecting the inner ear of the house mouse. J. Embryol. exp. Morph. 6, 105-116. 1958

18. Carter, T. C., Lyon, M. F. \& Phillips, R. J. S. Genetic hazard of ionizing radiations. Nature 182, 409. 1958

19. Lyon, M. F. \& Phillips, R. J. S. Crossing-over in mice heterozygous for $t$-alleles. Heredity 13, 23-32. 1959

20. Lyon, M. F. Some evidence concerning the 'mutational load' in inbred strains of mice. Heredity 13, 341-352. 1959

21. Lyon, M. F. A new dominant T-allele in the house mouse. J. Hered. 50, 140-142. 1959

22. Lyon, M. F. A further mutation of the mottled type in the house mouse. J. Hered. 51, 116-121. 1960

23. Lyon, M. F. Zigzag: a genetic defect of the horizontal canals in the mouse. Genet. Res., Camb. 1, 189-195. 1960

24. Lyon, M. F. Effect of X-rays on the mutation of $t$-alleles in the mouse. Heredity 14, 247-252. 1960

25. Duffill, M. L. \& Lyon, M. F. Flaked maize as a source of tape-worm infestation in mice. J. Anim. Tech. Assn. 10, (4). 1960

26. Carter, T. C., Lyon, .M. F. \& Phillips, R. J. S. The 
genetic sensitivity to X-rays of mouse foetal gonads. Genet. Res., Camb. 1, 351-355. 1960

27. The committee on standardized nomenclature for mice. (G. D. Snell, J. Staats, M. F. Lyon, L. C. Dunn, H. Gruneberg, P. Hertwig, W. E. Heston). Standardized Nomenclature for Inbred strains of Mice, Second Listing. Cancer Research 20, 145-169. 1960

28. Lyon, M. F. Linkage relations and some pleiotropic effects of the dreher mutant of the house mouse. Genet. Res., Camb. 2, 92-95. 1961

29. Lyon, M. F. Gene action in the X-chromosome of the mouse (Mus musculus L.) Nature 190, 372-373. 1961

30. Carter, T. C. \& Lyon, M. F. An attempt to estimate the induction by X-rays of recessive lethal and visible mutations in mice. Genet. Res., Camb. 2, 296-305. 1961

31. Lyon, M. F. Genetic factors on the X-chromosome. Lancet ii, 434.1961

32. Lyon, M. F. Sex-chromatin and gene action in the mammalian X chromosome. Amer.J. Hum. Genet. 14, 135-148. 1962

33. Lyon, M. F., Phillips, R. J. S. and Searle, A. G. A test for mutagenicity of caffeine in mice. $Z$. Vererbslehre 93, 7-13. 1962

34. Lyon, M. F. The nature of $t$-alleles in the mouse. Ann. Hum. Genet. 25, 263. 1961

35. Lyon, M. F. Attempts to test the inactive-X theory of dosage compensation in mammals. Ann. Hum. Genet. 25, 423. 1962

36. Lyon, M. F. Attempts to test the inactive- $X$ theory of dosage compensation in mammals. Genet. Res., Camb. 4, 93-103. 1963

37. Lyon, M. F. Mutant mice and their use in research. L.A.C. Collected Papers. 12, 57-63. 1963

38. Lyon, M. F. Genetics of the Mouse. In Animals for Research (ed. W. Lane Petter), ch. 7, pp. 199-234. London: Academic Press. 1963

39. Lyon, M. F. Lyonisation of the X-chromosome. Lancet ii, 1120-1121. 1963

40. Lyon, M. F. Gene action in the X-chromosome of mammals including man. Proc. IInd. int. Cong. Hum. Genet. 2, 1228-9. 1963

41. Lyon, M. F. - Sex chromosome, human. In McGrawHill Yearbook of Science and Technology, pp. 369-370. 1964

42, 43, 44. Lyon, M. F. \& Meredith, R. The nature of $t$ alleles in the mouse. I, II, III. Heredity 19, 301-312, 313-325, 327-330. 1964

45. Lyon, M. F., Phillips, R. J. S. \& Searle, A. G. The overall rates of dominant and recessive lethal and visible mutation induced by spermatogonial $\mathrm{X}$-irradiation of mice. Genet. Res., Camb. 5, 448-467. 1964

46. Lyon, M. F., Searle, A. G., Ford, C. E. \& Ohno, S. A mouse translocation suppressing sex-linked variegation. Cytogenetics 3, 306-323. 1964

47. Ohno, S. \& Lyon, M. F. Cytological study of Searle's $\mathrm{X}$-autosome translocation in Mus musculus. Chromosoma 16, 90-100. 1965

48. Evans, H. J., Ford, C. E., Lyon, M. F. \& Gray, J. DNA replication and genetic expression in female mice with morphologically distinguishable X-chromosomes. Nature 206, 900-903. 1965

49. Lyon, M. F., Hulse, E. V. \& Rowe, C. E. Foam-cell reticulosis of mice: an inherited condition resembling Gaucher's and Niemann-Pick diseases. J. Med. Genet. 2, 99-106. 1965

50. Lyon, M. F. \& Morris, T. Mutation rates at a new set of specific loci in the mouse. Genet. Res., Camb. 7, 12-17. 1966

51. Lyon, M. F. X-chromosome inactivation in mammals. In Advances in Teratology (ed. D. Woollam), ch. 2, pp. 25-54. London: Logos Press. 1966

52. Lyon, M. F. Order of loci on the X-chromosome of the mouse. Genet. Res., Camb. 7, 130-133. 1966

53. Lyon, M. F. Sex chromatin and gene action in the Xchromosome of mammals. In Sex Chromatin (ed. K. Moore), ch. 21, pp. 370-386. Philadelphia: W. B. Saunders. 1966

54. Lyon, M. F. \& Meredith, R. Autosomal translocations causing male sterility and viable aneuploidy in the mouse. Cytogenetics 5, 335-354. 1966

55. Lyon, M. F. Lack of evidence that inactivation of the mouse X-chromosome is incomplete. Genet. Res., Camb. 8, 197-203. 1966

56. Lyon, M. F. Selective genetic inactivation in somatic cells. In Genetic Variations in Somatic Cells (Proceedings of a Symposium held in Prague, 9-11 August 1965), pp. 139-143. 1966

57. Evans, E. P., Lyon, M. F. \& Daglish, M. A mouse translocation giving a metacentric marker chromosome. Cytogenetics 6, 105-119. 1967

58. Lyon, $M$. F. The $X$-chromosome and gene action in mammals. In The Biology of Sex (ed. A. Allison), pp. 121-134. Penguin Science Survey. 1967

59. Lyon, M. F., Morris, T., Searle, A. G. \& Butler, J. Occurrences and linkage relations of the mutant 'Extra-toes' in the mouse. Genet. Res., Camb. 9, 383-385. 1967

60. Lyon, M. F., Butler, J. M. \& Kemp, R. The positions of the centromeres in linkage groups II and IX of the mouse. Genet. Res., Camb. 11, 193-199. 1968

61. Lyon, M. F. Chromosomal and subchromosomal inactivation. Ann. Rev. Genet. 2, 31-52. 1968

62. Lyon, M. F. \& Morris, T. Gene and chromosome mutation after large fractionated for unfractionated radiation doses to mouse spermatogonia. Mutation Res. 8, 191-198. 1969

63. Lyon, M. F. A true hermaphrodite mouse presumed to be an $\mathrm{XO} / \mathrm{XY}$ mosaic. Cytogenetics 8, 326-331. 1969

64. Lyon, M. F. \& Meredith, R. Muted, a new mutant affecting coat colour and otoliths of the mouse, and its position in linkage group XIV. Genet. Res., Camb. 14, 163-166. 1969

65. Lyon, M. F., Morris, T., Glenister, P. \& O'Grady, S. E. Induction of translocations in mouse spermatogonia by X-ray doses divided into many small fractions. Mutation Res. 9, 219-223. 1970

66. Lyon, M. F. The activity of the sex chromosomes in mammals. Science Progress 58, 117-130. 1970

67. Savkovic, N. V. \& Lyon, M. F. Dose-response curve for X-ray-induced translocations in mouse spermatogonia. I. Single doses. Mutation Res. 9, 407-409. 1970

68. Lyon, M. F. X-ray induced dominant lethal mutations in male guinea-pigs, hamsters and rabbits. Mutation Res. 10, 133-140. 1970

69. Lyon, M. F. Genetic activity of sex chromosomes in somatic cells of mammals. Phil. Trans. Roy. Soc. B. 259, 41-52. 1970

70. Lyon, M. F., Phillips, R. J. S. \& Glenister, P. Doseresponse curve for the yield of translocations in mouse spermatogonia after repeated small radiation doses. Mutation Res. 10, 497-501. 1970

71. Ohno, S. \& Lyon, M. F. X-linked testicular feminization in the mouse as a non-inducible regulatory 
mutation of the Jacob-Monod type. Clinical Genetics 1, 121-127. 1970

72. Lyon, M. F. \& Hawkes, S. G. X-linked gene for testicular feminization in the mouse. Nature 227, 1217-1219. 1971

73. Lyon, M. F. \& Hulse, E. V. An inherited kidney disease of mice resembling human nephronophthisis. J. med. Genet. 8, 41-48. 1971

74. Lyon, M. F. \& Smith, B. D. Species comparisons concerning radiation-induced dominant lethals and chromosome aberrations. Mutation Res. 11, 45-58. 1971

75. Gardner, R. L. \& Lyon, M. F. X-chromosome inactivation studied by injection of a single cell into the mouse blastocyst. Nature 231, 385-386. 1971

76. Lyon, M. F. Possible mechanisms of X-chromosome inactivation. Nature, New Biology 232, 229-232. 1971

77. Lyon, M. F. Environmental radiation and genetic hazards to man. In Population and Pollution (ed. P. R. Cox and J. Peel), pp. 85-94. London: Academic Press. 1972

78. Lyon, M. F. X-chromosome inactivation and developmental patterns in mammals. Biol. Rev. 47, 1-35. 1972

79. Lyon, M. F., Phillips, R. J. S. \& Bailey, H. J. Mutagenic effects of repeated small radiation doses. I. Specific locus mutation rates. Mutation Res. 15, 185-190. 1972

80. Lyon, M. F., Phillips, R. J. S. \& Glenister, P. H. Mutagenic effects of repeated small radiation doses to mouse spermatogonia. II. Translocation yield at various intervals. Mutation Res. 15, 191-195. 1972

81. Cattanach, B. M., Wolfe, H. G. \& Lyon, M. F. A comparative study of the coats of chimaeric mice and those of heterozygotes for X-linked genes. Genet. Res., Camb. 19, 213-228. 1972

82. Lyon, M. F., Papworth, D. G. \& Phillips, R. J. S. Dose-rate and mutation frequency after irradiation of mouse spermatogonia. Nature, New Biology 238, 101-104. 1972

83. Lyon, M. F., Glenister, P. H. \& Hawker, S. G. Do the $\mathrm{H}-2$ and $\mathrm{T}$-loci of the mouse have function in the haploid phase of sperm? Nature 240, 152-153. 1972

84. Lyon, M. F., Phillips, R. J. S. \& Glenister, P. H. The mutagenic effect of repeated small radiation doses to mouse spermatogonia. III. Does repeated irradiation reduce translocation yield from a large radiation dose? Mutation Res. 17, 81-85. 1973

85. Lyon, M. F. \& Hawker, S. G. Reproductive lifespan in irradiated and unirradiated chromosomally XO mice. Genet. Res., Camb. 21, 185-194. 1973

86. Lyon, M. F., Hendry, I. \& Short, R. V. The submaxillary salivary glands as test organs for response to androgen in mice with testicular feminization. $J$. Endocr. 58, 357-362. 1973

87. Lyon, M. F. \& Glenister, P. H. Evidence from Tfm $/ O$ that androgen is inessential for reproduction in female mice. Nature 247, 366-367. 1974

88. Lyon, M. F. \& Simpson, G. M. An investigation into the possible genetic hazards of ultrasound. British Journal of Radiology 47, 712-722. 1974

89. Lyon, M. F. Review Lecture. Mechanisms and evolutionary origins of variable $\mathrm{X}$-chromosome activity in mammals. Proc. B. Soc. Lond. B. 187, 243-268. 1974

90. Lyon, M. F. Role of $X$ and $Y$ chromosomes in mammalian sex determination and differentiation. Helv. paediat. Acta Suppl. 34, 7-12. 1974

91. Lyon, M. F. Evolution of X-chromosome inactivation in mammals. Nature 250, 651-653. 1974
92. Lyon, M. F. Sex chromosome activity in germ cells. In Physiology and Genetics of Reproduction (ed. E. M. Coutinho and F. Fuchs), Part A, pp. 63-71. New York: Plenum. 1974

93. Lyon, M. F. Symposium No. 6: Gene and chromosome inactivation. Genetics 78, 305-309. 1974

94. Cox, B. D. \& Lyon, M. F. X-ray induced dominant lethal mutations in mature and immature oocytes of guinea-pigs and golden hamsters. Mutation Res. 28, 421-436. $\quad 1975$

95. Cox, B. D. \& Lyon, M. F. The induction by X-rays of chromosome aberrations in germ cells of male guineapigs, golden hamsters and rabbits. I. Dose response in post-meiotic stages. Mutation Res. 29, 93-109. 1975

96. Cox, B. D. \& Lyon, M. F. The induction by X-rays of chromosome aberrations in male guinea-pigs, golden hamsters and rabbits. II. Properties of translocations induced in post-meiotic stages. Mutation Res. 29, 111-125. 1975

97. Lyon, M. F. \& Cox, B. D. The induction by X-rays of chromosome aberrations in male guinea-pigs, rabbits and golden hamsters. III. Dose-response relationship after single doses of X-rays to spermatogonia. $\mathrm{Mu}$ tation Res. 29, 407-422. 1975

98. Lyon, M. F. \& Cox, B. D. The induction by X-rays of chromosome aberrations in male guinea-pigs and golden hamsters. IV. Dose response for spermatogonia treated with fractionated doses. Mutation Res. 30, 117-128. 1975

99. Cox, B. D. \& Lyon, M. F. The mutagenic effect of triethylenemelamine (TEM) on germ cells of male golden hamsters and guinea pigs. Mutation Res. 30, 293-298. 1975

100. Lyon, M. F. \& Phillips, R. J. S. Specific locus mutation rates after repeated small radiation doses to mouse oocytes. Mutation Res. 30, 375-382. 1975

101. Bennett, D., Boyse, E. A., Lyon, M. F., Mathieson, B. J., Scheid, M. \& Yanagisawa, K. Expression of H-Y (male) antigen in phenotypically female $\mathrm{Tfm} / \mathrm{Y}$ mice. Nature 257, 236-238. 1975

102. Lyon, M. F., Glenister, P. H. \& Lamoreux, M. L. Normal spermatozoa from androgen-resistant germ cells of chimaeric mice and the role of androgen in spermatogenesis. Nature 258, 620-622. 1975

103. Lyon, M. F. Implications of Freezing for the Preservation of Genetic Stocks. In Proceedings of the Workshop on Basic Aspects of Freeze Preservation of Mouse Strains (Jackson Laboratory, Bar Harbor, 16-18 September 1974). Stuttgart: Gustav Fischer. 1976

104. Lyon, M. F., Ward, H. C. \& Simpson, G. M. A genetic method for measuring non-disjunction in mice with Robertsonian translocations. Genet. Res., Camb. 26, 283-295. 1976

105. Lyon, M. F., Cox, B. D. \& Marston, J. H. Doseresponse data for $\mathrm{X}$-ray induced translocations in spermatogonia of rhesus monkeys. Mutation Res. 35, 429-436. 1976

106. Lyon, M. F. Chromosome condensation in relation to genetic activity. Reprinted from Life Sciences Research Report 4 (ed. V. G. Allfrey, E. K. F. Bautz, B. J. McCarthy, R. T. Schimke and A. Tissières). Dahlem Workshop on Organization and Expression of Chromosome. 1976

107. Kacser, H., Mya Mya, K., Duncker, M., Wright, A. F., Bulfield, G., McLaren, A. \& Lyon, M. F. Maternal histidine metabolism and its effect on foetal development in the mouse. Nature 265, 262-266. 1977

108. Lyon, M. F. Distribution of crossing-over in mouse chromosomes Genet. Res., Camb. 28, 291-299. 1976 
109. Lyon, M. F. \& Glenister, P. H. Factors affecting the observed number of young resulting from adjacent-2 disjunction in mice carrying a translocation. Genet. Res., Camb. 29, 83-92. 1977

110. Whittingham, D. G., Lyon, M. F. \& Glenister, P. H. Long-term storage of mouse embryos at $-196^{\circ} \mathrm{C}$ : the effect of background radiation. Genet. Res., Camb. 29, 171-181. 1977

111. Evans, E. P., Ford, C. E. \& Lyon, M. F. Direct evidence of the capacity of the XY germ cell in the mouse to become an oocyte. Nature 267, 430-431. 1977

112. Lyon, M. F. \& Mason, I. Information on the nature of $t$-haplotypes from the interaction of mutant haplotypes in male fertility and segregation ratio. Genet. Res., Camb. 29, 255-266. 1977

113. Lyon, M. F. \& Bechtol, K. B. Derivation of mutant $t$ haplotypes of the mouse by presumed duplication or deletion. Genet. Res., Camb. 30, 63-76. 1977

114. Lyon, M. F., Whittingham, D. G. \& Glenister, P. H. Long-term storage of frozen mouse embryos under increased background irradiation. Reprinted from The Freezing of Mammalian Embryos (Ciba Foundation Symposium 52, new series), pp. 273-290. 1977

115. Caine, A.\& Lyon, M. F. The induction of chromosome aberrations in mouse dictyate oocytes by X-rays and chemical mutagens. Mutation Res. 45, 325-331. 1977

116. Lyon, M. F. Genetic nomenclature and nomenclatorial rules in the mouse. Immunogenetics 5, 393-403. 1977

117. Whittingham, D. G., Lyon, M. F. \& Glenister, P. H. Re-establishment of breeding stocks of mutant and inbred strains of mice from embryos stored at $-196^{\circ} \mathrm{C}$ for prolonged periods. Genet. Res., Camb. 30, 287-299. 1977

118. Preston, R. J., Adler, I.-D., Léonard, A. \& Lyon, M. F. Mutagenicity of selected chemicals in in vivo cytogenetic assays. In Proceedings of the Workshop on Comparative Chemical Mutagenesis (Crabtree Valley Mall, Raleigh, North Carolina 30 October - 4 November 1977, Environmental Science Research, Vol. 24). 1977

119. Lyon, M. F. Section II - Chairman's Address. Reprinted from Reproduction and Evolution (ed. J. H. Calaby and C. H. Tyndale-Biscoe), pp. 95-98. Canberra: Australian Academy of Science. 1977

120. Kaufman, M. H., Guc-Cubrilo, M. \& Lyon, M. F. X chromosome inactivation in diploid parthenogenetic mouse embryos. Nature 271, 547-549. 1978

121. Bechtol, K. B. \& Lyon, M. F. H-2 typing of mutants of the $\mathrm{t}^{6}$ haplotype in the Mouse. Immunogenetics 6 , 571-583. 1978

122. Lyon, M. F. Standardized genetic nomenclature for mice: Past, Present and Future. From Origins of Inbred Mice (ed. H. C. Morse III), pp. 445-455. New York: Academic Press. 1978

123. Caine, A. \& Lyon, M. F. Reproductive capacity and dominant lethal mutations in female guinea-pigs and djungarian hamsters following $\mathrm{X}$-rays or chemical mutagens. Mutation Res. 59, 231-244. 1979

124. Lyon, M. F., Evans, E. P., Jarvis, S. E. \& Sayers, I. tHaplotypes of the mouse may involve a change in intercalary DNA. Nature 279, 38-42. 1979

125. Lyon, M. F., Jarvis, S. E. \& Sayers, I. Complementation reactions of a lethal mouse t-haplotype believed to include a deletion. Genet. Res., Camb. 33, 153-161. 1979

126. Lyon, M. F., Phillips, R. J. S. \& Fisher, G. Doseresponse curves for radiation-induced gene mutations in mouse oocytes and their interpretation. Mutation Res. 63, 161-173. 1979
127. Lyon, M. F. Nephronophthisis. From Spontaneous Animal Models of Human Disease, Vol. 2, (ed. E. J. Andrews, B. C. Ward and N. H. Altman) ch. 282, p. 274. New York: Academic Press. 1979

128. Lyon, M. F. \& Glenister, P. H. Reduced reproductive performance in androgen-resistant $T f m / T f m$ female mice. Proc. R. Soc. Lond. B. 208, 1-12. 1980

129. Rastan, S., Kaufman, M. H., Handyside, A. H. \& Lyon, M. F. X-chromosome inactivation in extraembryonic membranes of diploid parthenogenetic mouse embryos demonstrated by differential staining. Nature 288, 172-173. 1980

130. Lyon, M. F. Effects of radiation on fertility. Brit. $J$. Radiol. 54, 81-84. 1981

131. Lyon, M. F. The t-complex and the genetical control of development. Symp. Zool. Soc. Lond. 47, 455-477. 1981

132. Lyon, M. F., Cattanach, B. M. \& Charlton, H. M. Genes affecting sex differentiation in mammals. From Mechanisms of Sex Differentiation in Animals and Man (ed. C. R. Austin and R. G. Edwards), pp. 329-386. London: Academic Press. 1981

133. Lyon, M.F. Nomenclature. From The Mouse in Biomedical Research. Vol. 1 (ed. H. G. Foster, J. D. Small and J. G. Fox), ch. 3, pp. 27-38. New York: Academic Press. 1981

134. Lyon, M. F., Jarvis, S. E., Sayers, I. \& Holmes, R. S. Lens opacity: a new gene for congenital cataract on chromosome 10 of the mouse. Genet. Res., Camb. 38, 337-341. 1981

135. Lyon, M. F., Glenister, P. H. \& Whittingham, D. G. Long-term viability of embryos stored under irradiation. From Frozen Storage of Laboratory Animals (ed. G. H. Zeilmaker), pp. 139-147. Stuttgart, New York: Gustav Fischer. 1981

136. Lyon, M. F. Rules for nomenclature of inbred strains. From Genetic Variants and Strains of the Laboratory Mouse (ed. M. C. Green), pp. 368-372. Stuttgart, New York: Gustav Fischer. 1981

137. Lyon, M. F. Miss Rita J. S. Phillips (obituary). Mutation Res. 81, 263-264. 1981

138. Lyon, M. F. Rules and guidelines for gene nomenclature. From Genetic Variants and Strains of the Laboratory Mouse (ed. M. C. Green), pp. 1-7. Stuttgart, New York: Gustav Fischer. 1981

139. Lyon, M. F. Rules for nomenclature of chromosome anomalies. From Genetic Variants and Strains of the Laboratory Mouse (ed. M. C. Green), pp. 314-316. Stuttgart, New York: Gustav Fischer. 1981

140. Glenister, P. H. \& Lyon, M. F. Experience of banking mutant genes. From Frozen Storage of Laboratory Animals (ed. G. H. Zeilmaker), pp. 157-163. Stuttgart, New York: Gustav Fischer. 1981

141. Lyon, M. F. Sensitivity of various germ-cell stages to environmental mutagens. Mutation Res. 87, 323-345. 1981

142. Dalton, T. P., Edwards, J. H., Evans, E. P., Lyon, M. F., Parkinson, S. P., Peters, J. \& Searle, A. G. Chromosome maps of man and mouse. Clinical Genetics 20, 407-415. 1981

143. Lyon, M. F., Phillips, R. J. S. \& Fisher, G. Use of an inversion to test for induced $\mathrm{X}$-linked lethals in mice. Mutation Res. 92, 217-228. 1982

144. Lyon, M. F. \& Glenister, P. H. A new allele sash ( $\left.W^{\text {sh }}\right)$ at the $W$-locus and a spontaneous recessive lethal in mice. Genet. Res., Camb. 39, 315-322. 1982

145. Kirk, M. \& Lyon, M. F. Induction of congenital anomalies in offspring of female mice exposed to varying doses of X-rays. Mutation Res. 106, 73-83. 1982 
146. Lyon, M. F. Problems of extrapolation from experimental data to human mutagenesis. In Mutagens in our Environment, pp. 127-136. New York: Alan R. Liss. 1982

147. Fritz, I. B., Lyon, M. F. \& Setchell, B. P. Evidence for a defective seminiferous tubule barrier in testes of $\mathrm{Tfm}$ and Sxr mice. J. Reprod. Fert. 67, 359-363. 1983

148. Lyon, M. F. \& Loutit, J. F. X-linked factor in acquired immunodeficiency syndrome? The Lancet, 2 April, pp. 768. 1983

149. Lyon, M. F. The cryptic spread of mutant genes. Ambio 75-77. 1983

150. Lyon, M. F. Problems in extrapolation of animal data to humans. In Utilization of Mammalian Specific Locus Studies in Hazard Evaluation and Estimation of Genetic Risk (ed. F. J. de Serres and W. Sheridan), pp. 289305. Plenum Publishing Corporation. 1983

151. Lyon, M. F. The use of Robertsonian translocations for studies of nondisjunction. In Radiation-induced Chromosome Damage in Man, pp. 327-346. New York: Alan R. Liss. 1983

152. Lyon, M. F. The X chromosomes and their levels of activation. In Cytogenetics of the Mammalian $X$ Chromosome, Part A, Basic Mechanisms of X Chromosome Behaviour, ch. 8, pp. 187-204. New York: Alan R. Liss. 1983

153. Kirk, K. M. \& Lyon, M. F. Induction of congenital malformations in the offspring of male mice treated with X-rays at pre-meiotic and post-meiotic stages. Mutation Res. 125, 75-85. 1984

154. Glenister, P. H., Whittingham, D. G. \& Lyon, M. F. Further studies on the effect of radiation during the storage of frozen 8 -cell mouse embryos at $-196^{\circ} \mathrm{C} . J$. Reprod. Fert. 70, 229-234. 1984

155. Lyon, M. F. Comparison of the dominant visible and other mutation tests in the mouse. Mutagenesis and Genetic Toxicology INSERM 119, 153-164. 1983

156. Lyon, M. F. Estimation of genetic risks and increased incidence of genetic disease due to environmental mutagens. Mutation Res. 115, 255-291. 1983

157. Lyon, M. F. \& Rastan, S. Parental source of chromosome imprinting and its relevance for $\mathrm{X}$ chromosome inactivation. Differentiation 26, 63-67. 1984

158. Dudley, K., Potter, J., Lyon, M. F. \& Willison, K. R. Analysis of male sterile mutations in the mouse using haploid stage expressed cDNA probes. Nucleic Acids Research, vol. 12, 4281-4293. 1984

159. Lyon, M. F. Transmission ratio distortion in mouse thaplotypes is due to multiple distorter genes acting on a responder locus. Cell 37, 621-628. 1984

160. Buckle, V. J., Edwards, J. H., Evans, E. P., Jonasson, J. A., Lyon, M. F., Peters, J., Searle, A. G. \& Wedd, N.S. Chromosome maps of man and mouse II. Clinical Genetics 26, 1-11. 1984

161. Lyon, M. F., Glenister, P. H., Loutit, J. F., Evans, E. P. \& Peters, J. A presumed deletion covering the $W$ and $P h$ loci of the mouse. Genet. Res., Camb. 44 161-168. 1984

162. Lyon, M. F. Evidence from genetic analysis of the mouse t-complex concerning its role in development. Journal of Embryology and Experimental Morphology 82, Supplement p. 9.1984

163. Lyon, M. F. Further data on the genetic basis of segregation distortion and sterility caused by Mouse thaplotypes. Genetical Research 43, 205. 1984

164. West, J. D., Peters, J. \& Lyon, M. F. Genetic differences between two substrains of the inbred 101 mouse strain. Genet. Res., Camb. 44, 343-346. 1984

165. Fox, H. S., Martin, G. R., Lyon, M. F., Herrmann, B., Frischauf, A.-M., Lehrach, H. \& Silver, L. M.
Molecular probes define different regions of the mouse $t$ complex. Cell 40, 63-69. 1985

166. West, J. D., Kirk, K. M., Goyder, Y. \& Lyon, M. F Discrimination between the effects of $\mathrm{X}$-ray irradiation of the mouse oocyte and uterus on the induction of dominant lethals and congenital anomalies. I. Embryotransfer experiments. Mutation Res. 149, 221-230. 1985

167. West, J. D., Kirk, K. M., Goyder, Y. \& Lyon, M. F Discrimination between the effects of $\mathrm{X}$-ray irradiation of the mouse oocyte and uterus on the induction of dominant lethals and congenital anomalies. II. Localised irradiation experiments. Mutation Res. 149, 231-238. 1985

168. Loutit, J. F., Cattanach, B. M. \& Lyon, M. F. The gene triplet $R w W P h$ controls murine haematopoiesis British Journal of Haematology 60, 219-232. 1985

169. Lyon, M. F. Attempts to estimate genetic risks caused by mutagens to later generations. Reprinted from Banbury Report 19: Risk Quantitation and Regulatory Policy, pp. 151-161. Cold Spring Harbor. 1985

170. Lyon, M. F., Fisher, G. \& Glenister, P. H. A recessive allele of the mouse agouti locus showing lethality with yellow, A ${ }^{\mathbf{Y}}$. Genet. Res., Camb. 46, 95-99. 1985

171. Gardner, R. L., Lyon, M. F., Evans, E. P. \& Burtenshaw, M. D. Clonal analysis of X-chromosome inactivation and the origin of the germ line in the mouse embryo. Journal of Embryology and Experimental Morphology 88, 349-363. 1985

172. West, J. D., Lyon, M. F. \& Peters, J. Genetic differences between substrains of the inbred mouse strain 101 and designation of a new strain 102. Genet. Res., Camb. 46, 349-352. 1985

173. Rogers, J. H., Lyon, M. F. \& Willison, K. R. The arrangement of $\mathrm{H}-2$ class I genes in mouse $t$ haplotypes. Journal of Immunogenetics 12, 151-165. 1985

174. Lyon, M. F. Measuring mutation in man. Nature 318, 315-316. 1985

175. Lyon, M. F. Male sterility of the mouse t-complex is due to homozygosity of the distorter genes. Cell $\mathbf{4 4}$ 357-363. 1986

176. Glenister, P. H. \& Lyon, M. F. Long-term storage of eight-cell mouse embryos at $-196^{\circ} \mathrm{C}$. Journal of in vitro Fertilization and Embryo Transfer 3, 20-27. 1986

177. Lyon, M. F. X chromosomes and dosage compensation. Nature 320, 313.1986

178. Lyon, M. F., Scriver, C. R., Baker, L. R. I., Tenenhouse, H. S., Kronick, J. \& Mandla, S. The Gy mutation: Another cause of X-linked hypophosphatemia in mouse. Proc. Natl. Acad. Sci. USA 83, 4899-4903. 1986

179. Lyon, M. F., Zenthon, J., Evans, E. P., Burtenshaw, M. D., Wareham, K. A. \& Williams, E. D. Lack of inactivation of a mouse $\mathrm{X}$-linked gene physically separated from the inactivation centre. J. Embryol. exp. Morph. 97, 75-85. 1986

180. Lyon, M. F. \& Renshaw, R. Induction of congenital malformations in the offspring of mutagen treated mice. Genetic Toxicology of Environmental Chemicals, Part B: Genetic Effects and Applied Mutagenesis, pp. 449-458. New York: Alan R. Liss. 1986

181. Hogan, B. L. M., Horsburgh, G., Cohen, J., Hetherington, C. M., Fisher, G. \& Lyon, M. F. Small eyes (Sey): a homozygous lethal mutation on chromosome 2 which affects the differentiation of both lens and nasal placodes in the mouse. $J$. Embryol. exp. Morph. 97, 95-110. 1986

182. Lyon, M. F., Zenthon, J., Evans, E. P., Burtenshaw, M. D., Dudley, K. \& Willison, K. R. Location of the 
$t$-complex on mouse chromosome 17 by in situ hybridization with Tcp-1. Immunogenetics 24, 125-127. 1986

183. Brown, S. D. M., Fisher, E. M. C., Brockdorff, N., Cavanna, J. S., Lyon, M. F. \& Greenfield, A. J. Microcloning of mouse chromosome $\mathrm{X}$ and 7 for the analysis of the $m d x$ and pudgy loci. Mouse News Letter 76, 44.1986

184. Lyon, M. F. Is the incidence of Down syndrome increasing? Mutation Res. 175, 263-266. 1986

185. Lyon, M. F. Nomenclature for homoeobox-containing genes. Nature 325, 21-22. 1987

186. Lyon, M. F. Distorter genes of the mouse $t$-complex impair male fertility when heterozygous. Genet. Res., Camb. 49, 57-60. 1987

187. Lyon, M. F., Zenthon, J., Burtenshaw, M. D. \& Evans, E. P. Localization of the Hprt locus by in situ hybridization and distribution of loci on the mouse $\mathrm{X}$. chromosome. Cytogenet. Cell Genet. 44, 163-166. 1987

188. Brockdorff, N., Fisher, E. M. C., Cavanna, J., Lyon, M. F. \& Brown, S. D. M. The molecular mapping of the mouse X-chromosome. Genet. Res., Camb. 49, 258. 1987

189. Wareham, K. A., Williams, E. D., Glenister, P. H., Zenthon, J., Lyon, M. F. \& Evans, E. P. Data from mouse $\mathrm{X}$-autosome translocations on $\mathrm{X}$-chromosome inactivation and reactivation. Genet. Res., Camb. 49, 260. 1987

190. Wareham, K. A., Lyon, M. F., Glenister, P. H. \& Williams, E. D. Age related reactivation of an Xlinked gene. Nature 327, 725-727. 1987

191. Brockdorff, N., Cross, G. S., Cavanna, J. S., Fisher, E. M. C., Lyon, M. F., Davies, K. E. \& Brown, S. D. M. The mapping of a cDNA from the human $\mathrm{X}$-linked Duchenne muscular dystrophy gene to the mouse $\mathrm{X}$ chromosome. Nature 328, pp. 166-168. 1987

192. Lyon, M. F. \& Zenthon, J. Differences in or near the responder region of complete and partial mouse $t$ haplotypes. Genet. Res., Camb. 50, 29-34. 1987

193. Brockdorff, N., Fisher, E. M. C., Cavanna, J. S., Lyon, M. F. \& Brown, S. D. M. Construction of a detailed molecular map of the mouse $\mathrm{X}$ chromosome by microcloning and interspecific crosses. The EMBO Journal, 6, no. 11, 3291-3297. 1987

194. Searle, A. G., Peters, J., Lyon, M. F., Evans, E. P., Edwards, J. H. \& Buckle, V. J. Chromosome maps of man and mouse, III. Genomics 1, 3-18. 1987

195. Lyon, M. F., Zenthon, J., Evans, E. P., Burtenshaw, M. D. \& Willison, K. R. Extent of the mouse $t$ complex and its inversions shown by in situ hybridization. Immunogenetics 27, 375-382. 1988

196. Lyon, M. F. \& Renshaw, R. Induction of congenital malformation in mice by parental irradiation: transmission to later generations. Mutation Research 198, 277-283. 1988

197. Lyon, M. F. The William Allan Memorial Award Address: $\mathrm{X}$-chromosome inactivation and the location and expression of X-linked genes. Am. J. Hum. Genet. 42, 8-16. 1988

198. Lyon, M. F. Experimental work on induced mutations. Phil. Trans. R. Soc. Lond. B 319, 341-351. 1988

199. Lyon, M. F. Editorial. Clones and X-chromosomes. Journal of Pathology 155, 97-99. 1988

200. Nasir, J., Fisher, E. M. C., Brockdorff, N., Lyon, M. F. \& Brown, S. D. M. A novel repeat sequence island on the mouse X chromosome. Genet. Res., Camb. 52, 69.1988

201. Lyon, M. F., Zenthon, J., Evans, E. P., Burtenshaw,
M. D. \& Willison, K. R. t-complex inversions visualized by in situ hybridization. Genet. Res., Camb. 52, 61. 1988

202. Peters, J., Ball, S. T., Zenthon, J. \& Lyon, M. F Ornithine transcarbamylase (Otc) activity in mice carrying X-autosome translocations. Genet. Res., Camb. 52, 62. 1988

203. Lyon, M. F., Barker, J. E. \& Popp, R. A. Mouse globin gene nomenclature. Journal of Heredity 79, 93-95. 1988

204. Brown, S. D. M., Brockdorff, N., Cavanna, J. S., Fisher, E. M. C., Greenfield, A. J., Lyon, M. F. \& Nasir, J. The long-range mapping of mammalian chromosomes. Current Topics in Microbiology and Immunology vol. 137, pp. 3-12. Heidelberg: SpringerVerlag Berlin. 1988

205. Nasir, J., Fisher, E. M. C., Brockdorff, N., Lyon, M. F. \& Brown, S. D. M. A repeat sequence island on the mouse $\mathrm{X}$ chromosome. Genome 30, suppl. $1,98$. 1988

206. Willison, K., Marsh, M. \& Lyon, M. F. Biochemical evidence for sharing of gene products in spermatogenesis. Genet. Res., Camb. 52, 63.1988

207. Lyon, M. F. \& Searle, A. G. (eds). Genetic Variants and Strains of the Laboratory Mouse, 2nd edn, Oxford: Oxford University Press. 1989

208. Lyon, M. F., Herrmann, B. \& Whitehill, K. Phenotypic effects of a presumed deletion of t-complex distorter-1 resemble the t-complex allele rather than wild type. Genet. Res., Camb. 53, 227. 1989

209. Lyon, M. F. Rules and Guidelines for Gene Nomenclature. Genetic Variants and Strains of the Laboratory Mouse, 2nd edn (ed. M. F. Lyon and A. G. Searle), pp. 1-11. Oxford: Oxford University Press. 1989

210. Lyon, M. F. Rules for nomenclature of chromosome anomalies. Genetic Variants and Strains of the Laboratory Mouse, 2nd edn (ed. M. F. Lyon and A. G. Searle), pp. 574-575. Oxford: Oxford University Press. 1989

211. Lyon, M. F. Rules for Nomenclature of Inbred Strains. Genetic Variants and Strains of the Laboratory Mouse, 2nd edn (ed. M. F. Lyon and A. G. Searle), pp. 632-635. Oxford: Oxford University Press. 1989

212. Lane, P. W. \& Lyon, M. F. Mutant Genes and Biochemical Loci. Genetic Variants and Strains of the Laboratory Mouse, 2nd edn (ed. M. F. Lyon and A. G. Searle), pp. 825-842. Oxford: Oxford University Press. 1989

213. Lyon, M. F. X-chromosome inactivation as a system of gene dosage compensation to regulate gene expression. Progress in Nucleic Acid Research and Molecular Biology 36, 119-130. 1989

214. Searle, A. G., Peters, J., Lyon, M. F., Hall, J. G., Evans, E. P., Edwards, J. H. \& Buckle, V. J. Chromosome maps of man and mouse. IV. Ann. Hum. Genet. 53, 89-140. 1989

215. Willison, K., Lewis, V., Zuckerman, K. S., Cordell, J., Dean, C., Miller, K., Lyon, M. F. \& Marsh, M. The $t$ complex polypeptide 1 (TCP-1) is associated with the cytoplasmic aspect of Golgi membranes. Cell 57, 621-632. 1989

216. Lyon, M. F. Search for differences among $t$ haplotypes in distorter and responder genes. Genet. Res., Camb. 55, 13-19. 1990

217. Lyon, M. F., Peters, J., Glenister, P. H., Ball, S. \& Wright, E. The scurfy mouse mutant has previously unrecognised hematological abnormalities and resembles Wiskott-Aldrich Syndrome. Proc. Nat. Acad. Sci. USA 87, 2433-2437. 1990 